\title{
BMJ Open Vitamin D status among adults (18-65 years old) attending primary healthcare centres in Qatar: a cross-sectional analysis of the Electronic Medical Records for the year 2017
}

Abdul-Jaleel A Latif Zainel, ${ }^{\odot}$ Hamda Qotba, Ahmed Al Nuaimi, Mohamed Syed

To cite: Zainel A-JAL, Qotba $\mathrm{H}$, Al Nuaimi A, et al. Vitamin D status among adults (18-65 years old) attending primary healthcare centres in Qatar: a cross-sectional analysis of the Electronic Medical Records for the year 2017. BMJ Open 2019;9:e029334. doi:10.1136/ bmjopen-2019-029334

- Prepublication history and additional material for this paper are available online. To view these files, please visit the journal online (http://dx.doi. org/10.1136/bmjopen-2019029334).

Received 22 January 2019 Revised 16 July 2019 Accepted 26 July 2019
Check for updates

(c) Author(s) (or their employer(s)) 2019. Re-use permitted under CC BY-NC. No commercial re-use. See rights and permissions. Published by BMJ.

Research Department, Clinical Affairs Directorate, Primary Health Care Corporation, Doha, Qatar

Correspondence to

Dr Abdul-Jaleel A Latif Zainel; azainel@phcc.gov.qa

\section{ABSTRACT}

Objectives To investigate the prevalence of vitamin D deficiency among individuals attending primary healthcare facilities in Qatar and to assess the association between vitamin $D$ deficiency and some medical conditions in persons aged 18-65 years old.

Setting The study was undertaken in publicly funded primary healthcare services in the State of Qatar. Participants A total of 102342 participants aged between 18 and 65 years old with a valid serum vitamin D test result during the year 2017.

Outcome measures Serum level $<10 \mathrm{ng} / \mathrm{mL}(<25 \mathrm{nmol} / \mathrm{L})$ was defined as severe vitamin $D$ deficiency, a serum level of $<20 \mathrm{ng} / \mathrm{mL}(<50 \mathrm{nmol} / \mathrm{L})$ was defined as vitamin $D$ deficiency and a serum level $<30 \mathrm{ng} / \mathrm{mL}(<75 \mathrm{nmol} / \mathrm{L})$ defined as vitamin $D$ insufficiency.

Results The prevalence rate of severe vitamin D deficiency was $14.1 \%$ among study participants with no history of vitamin $D$ replacement therapy in the previous months. The prevalence rate of vitamin D deficiency was as high as $71.4 \%$ and that of vitamin $D$ insufficiency was up to $92.7 \%$. None of the five chronic conditions explored in the study (diabetes, hypertension, asthma, stroke and cardiovascular disease) had an obvious association with severe vitamin $\mathrm{D}$ deficiency status in a bivariate analysis. However, multivariate modelling showed that (adjusting for age, gender, body mass index and nationality and each of the included chronic conditions) hypertension, cardiovascular diseases and stroke placed an individual at a higher risk of having an associated severe vitamin D deficiency status.

Conclusion Although not comprehensive and nationally representative, this study is suggestive of a higher prevalence of vitamin $D$ deficiency among young adults, females, Qatari nationality and those with higher body mass index. Multivariate modelling showed that hypertension, cardiovascular diseases and stroke were associated with a higher risk of severe vitamin D deficiency status.

\section{INTRODUCTION}

Vitamin D is a steroid vitamin, which together with other physiological factors, controls the metabolism of calcium and phosphorus.
Strengths and limitations of this study

- An advantage of this study is that it used readily available data, which required fewer resources compared with collecting new data. The conclusions were therefore based on a very large set of data.

- The current cross-sectional study is not suitable to demonstrate temporality of any observed association. A longitudinal study design is needed to measure the risk of vitamin $D$ deficiency for selected predisposing factors or determinants with confidence.

- Variability in the applied diagnostic criteria and laboratory cut-off values in identifying vitamin D deficiency and insufficiency across different studies may limit the ability of a fair comparison.

- Selection bias is an obvious limitation in this study. Physicians are expected to order serum vitamin D test for specific service users according to special criteria and indications or personal preference, since no clear guideline are available for ordering the test. Therefore, not all people had equal chances to be included in this study.

There are different sources of vitamin D. Mainly exposure to the sun where ultraviolet $B$ radiation promotes synthesis of vitamin D in the skin. ${ }^{1}$ Diet also plays a role on vitamin D status. ${ }^{2}$ The major dietary sources of vitamin $\mathrm{D}$ are milk, plant-based beverages, fortified fruit juices and yogurts. ${ }^{3}$ Vitamin D deficiency can have serious consequences on health and is a widely spread micronutrient problem globally. Several risk factors are associated with low serum levels of vitamin $\mathrm{D}$ in adults. These include advancing age, female gender, clothing style, season, socioeconomic status, urban living, dark skin and body mass index (BMI). ${ }^{45}$

Vitamin D deficiency has been reported as a public health concern globally. ${ }^{6}$ While high prevalence of vitamin D deficiency has been 
reported globally, reliance on a single cut-off value to define vitamin D deficiency or insufficiency is problematic because of the wide individual variability of the functional effects of vitamin D and interaction with calcium intakes. ${ }^{6}$ In studies, cut-off values are often chosen when there is evidence of decreased risk for selected end-points for individuals with serum levels greater than that cut-off value. These end-points include fractures, cardiovascular diseases, colorectal cancer, diabetes, depressed mood, cognitive decline and death. ${ }^{7}$ Some published studies demonstrated vitamin $\mathrm{D}$ deficiency can be diagnosed when the level of serum vitamin $\mathrm{D}$ is $<25 \mathrm{nmol} / \mathrm{L}$ $(<10 \mathrm{ng} / \mathrm{mL}){ }^{8}$ Others defined deficiency as serum vitamin $\mathrm{D}<50 \mathrm{nmol} / \mathrm{L}(<20 \mathrm{ng} / \mathrm{mL}) .{ }^{7}$ The desirable level for an adult is $>75 \mathrm{nmol} / \mathrm{L}(>30 \mathrm{ng} / \mathrm{mL})$. A U shape relation between serum vitamin $\mathrm{D}$ level and adverse outcome was noticed. A level of $>250 \mathrm{nmol} / \mathrm{L}(>100 \mathrm{ng} / \mathrm{mL})$ invites problems. ${ }^{8}$ A level of $20-30 \mathrm{ng} / \mathrm{mL}$ of serum vitamin D is known as insufficient or suboptimal vitamin D status. ${ }^{8}$

Recently, vitamin D as a micronutrient and its deficiency has become more popular among the medical community as well as the public. Vitamin D deficiency in known to cause bone diseases in adults. ${ }^{9}{ }^{10} \mathrm{~A}$ study showed a positive correlation between bone mineral density values at both lumbar spine (L1-L4) and neck of femur and serum vitamin D levels, respectively. ${ }^{11}$ Apart from the well-established effect of vitamin D deficiency on diseases associated with bone growth, there is a wide array of other risk factors and medical conditions which in literature provide conflicting evidence of being associated with vitamin $\mathrm{D}$ deficiency.

A systematic review showed an increase in the prevalence of vitamin $\mathrm{D}$ deficiency with age. ${ }^{12}$ While a study conducted in Morocco, concluded that one of the main determinants of hypovitaminosis $\mathrm{D}$ was age $>55$ years. ${ }^{13}$ While in a Saudi study, vitamin D deficiency was reported to be common among older men with no education and sedentary lifestyle. ${ }^{11}$ Joergensen and colleagues found that vitamin $\mathrm{D}$ level was not associated with gender. ${ }^{14}$ While a study conducted in Qatar reported that the mean overall vitamin D level was lower in females compared with males. ${ }^{15}$ This gender inequality was also reported by another study from the United Arab Emirates (UAE) ${ }^{16}$

Vitamin D deficiency was found to be common among obese men with no education and sedentary lifestyle in a Saudi study. ${ }^{11}$ This observation was reported in another study on a group of healthy, white, obese medical school personnel, which showed that BMI was inversely correlated with serum vitamin D3 concentrations. ${ }^{5}$ Clothing which covers all parts of the body, spending time outdoors for less than 30 minutes/day and urban living have shown negative effects on the level of serum vitamin D. ${ }^{13} 17$ Spending more than 1 hour outdoors was independently associated with higher vitamin D levels. ${ }^{18}$

Evidence of other diseases and conditions, which may deteriorate or improve according to the level of serum vitamin $\mathrm{D}$ through an indirect mechanism are also available. Diabetes mellitus is more likely with vitamin D deficiency, as vitamin D acts through several mechanisms on glucose metabolism. Literature showed that Vitamin D can act on insulin producing cells ( $\beta$ cells) in the pancreas to produce more insulin, it acts on the muscle and fat cells to improve insulin action by reducing insulin resistance as well as vitamin D indirectly improves insulin production and its action by improving the level of calcium inside the cells. ${ }^{14}{ }^{19-21}$ In a study from Spain, vitamin D concentrations correlated negatively with total cholesterol and low-density lipoproteins (LDL) cholesterol levels. ${ }^{18}$ Colorectal cancer mortality was inversely related to serum vitamin $\mathrm{D}$ level, with levels $80 \mathrm{nmol} / \mathrm{L}$ or higher associated with a $72 \%$ risk reduction compared with lower than $50 \mathrm{nmol} / \mathrm{L}^{2}{ }^{2}$ A cross-sectional study showed a positive correlation between bone mineral density values at both lumbar spine (L1-L4) and neck of femur and serum vitamin D levels, respectively. ${ }^{11}$

In Qatar, prevalence of vitamin D deficiency has been reported as $90 \% .^{12}{ }^{15}$ The current study aims to investigate the prevalence of vitamin D deficiency among adult persons attending primary healthcare facilities in Qatar. In addition, it assessed the association between vitamin D deficiency and selected medical conditions (diabetes, asthma, hypertension, cardiovascular diseases and stroke) in people aged 18-65 years old. The current study will test the hypothesis that these selected medical conditions are associated with vitamin $\mathrm{D}$ status to provide a muchneeded snapshot of the extent of this micronutrient deficiency in the State of Qatar.

\section{METHODS \\ Study design \\ Cross-sectional study.}

\section{Study setting}

Qatar, a peninsular Arab country with a high-income economy backed by the world's third-largest natural-gas reserves, has been investing significantly on its healthcare system. This includes a publicly funded primary healthcare service delivered by the Primary Health Care Corporation (PHCC) which is the largest primary care provider publicly funded by the State of Qatar. At the time of undertaking this study, PHCC had 23 primary healthcare centres (all accredited by Accreditation Canada International) distributed across the country on three geographical regions. Every resident in Qatar with a valid residence permit is eligible to register with a PHCC health centre for a nominal annual fee and utilise its services.

\section{Study population}

A total of 102342 Electronic Medical Records (EMR) were extracted from PHCC's EMR system for service users aged between 18 and 65 years old with a valid serum vitamin D test result during the year 2017. 


\section{Study variables}

The outcome variable was vitamin D deficiency which was tested at three cut-off values. The independent (exposure) variables included age, gender, nationality, BMI and a list of selected chronic medical conditions. These included diabetes, hypertension, asthma, stroke and cardiovascular disease.

\section{Data collection}

In PHCC, individuals are tested for vitamin D serum levels if requested by a doctor. The tests are conducted in health centre laboratories. Blood drawn from an individual by a phlebotomist was processed using an Abbott ARCHETICT i1000SR IMMUNO analyzer designed to perform automated immunoassay tests, utilisingchemiluminescent microparticle assay detection technology. The results of the test were recorded by the laboratory on PHCC's EMR system. The laboratory internal quality control was conducted at the beginning of morning shift and judged by Westgard rules and Levey Jennings plot one time per day. The external quality control followed the Randox International Quality Assessment Scheme protocol. Data were extracted from the PHCC's EMR system for the defined study population. The data was extracted for a time period of 1 year starting from 1 January to 31 December 2017. A total of 421283 adults (aged 18-65 years old) accessed primary healthcare services in 2017. Out of those active users, 102342 individuals had a valid serum vitamin $\mathrm{D}$ measurement during the 1-year study period. The PHCC EMR system uses SNOMED codes (a systematically organised computer processable collection of medical terms providing codes, terms, synonyms and definitions used in clinical documentation and reporting). These codes are quality controlled and reviewed by the Health Information Management (HIM) department of PHCC. The HIM department is responsible for translating SNOMED codes into ICD-10 codes (International Classification of Disease the 10th Revision) and continuously updating the coding manual with any new code used in the organisational database at a monthly interval. The HIM department provided a full list of variables for the study population using filters requested for the purpose of the study. The codes and algorithms used for specifying the data extraction process is described in online supplementary appendix A.

\section{Data analysis}

The Statistical Package for Social Sciences (V.23) was used for data analysis. Descriptive statistics were done first. Data cleaning involved logical checks for consistency of related variables (like being treated with Vitamin D replacement and the type of formulary used for treatment being valid for those treated only) and range checks for dates to be within the specified study time.

A review of the literature suggests many cut-off values for defining vitamin $\mathrm{D}$ inadequacy. For the purposes of this study, severe vitamin D deficiency was defined as having a serum level of $<10 \mathrm{ng} / \mathrm{mL}$, vitamin D deficiency was defined as having a serum level of $<20 \mathrm{ng} / \mathrm{mL}$ and vitamin $\mathrm{D}$ insufficiency was defined as having a serum level of $<30 \mathrm{ng} / \mathrm{mL}$.

As treatment with replacement therapy was expected to affect the measured concentration of serum vitamin $\mathrm{D}$, the extracted data was split into two groups. The individuals treated with vitamin $\mathrm{D}$ replacement therapy before the date label for testing serum concentration of vitamin D were included in the treatment group while the others in the untreated group.

Age was recoded into age groups of 10 years intervals. Only the first (18-29 years) and last (50-65 years) age groups were different in class interval width. BMI in $\mathrm{kg}$ / $\mathrm{m}^{2}$ was classified into five groups using the WHO classification. These groups were: acceptable $(<25)$, overweight (25-29.9), grade 1 or low risk obesity (30-34.9), grade 2 or moderate risk obesity (35-39.9) and obesity grade 3 (morbid obesity) (40+). The season during which testing of vitamin D took place was classified into quarters of a year (the first quarter, for example, included the months of January, February and March).

Multivariate discriminant analysis was used to predict a severe vitamin D status based on age, nationality, gender, BMI and comorbid chronic conditions. The multivariate modelling helped to control the confounding effect of all the explanatory variables included in the model. No test of significance was needed since all the population with available data was analysed and no attempt is made to generalise the conclusion to an untested population.

\section{Quality control measures}

In the preparation phase of the study, an extensive review of literature was undertaken and academic experts in community medicine and other related fields were consulted. The study authors were responsible for data collection in collaboration with the HIM department. Collection of blood and its laboratory analysis followed PHCC's standard operating procedures.

\section{Ethical consideration}

The study presented minimal risk of harm to its human participants. The data collected was anonymised. None of the study participants' personal information was revealed to the research team.

\section{Patient and public involvement}

Patients' priorities, experience and preferences were not gathered nor were they involved in designing the study. PHCC's HIM department facilitated data collection. There are no plans to disseminate results to the study participants directly as they are already anonymised.

\section{RESULTS}

The study results are based on the analysis of 102342 primary healthcare service users (adults between 18 and 65 years old) with a valid serum vitamin $\mathrm{D}$ test result during the year 2017 as shown in table 1 . 
Table 1 Frequency distribution of the total study sample with an available recorded value for serum vitamin $\mathrm{D}$ during the year 2017

\begin{tabular}{|c|c|c|}
\hline & $\mathbf{N}$ & $\%$ \\
\hline \multicolumn{3}{|l|}{ Age group in years } \\
\hline $18-29$ & 23348 & 22.8 \\
\hline 30-39 & 30889 & 30.2 \\
\hline $40-49$ & 24736 & 24.2 \\
\hline $50-65$ & 23369 & 22.8 \\
\hline Total & 102342 & 100.0 \\
\hline \multicolumn{3}{|l|}{ Gender } \\
\hline Female & 67393 & 65.9 \\
\hline Male & 34946 & 34.1 \\
\hline Total & 102339 & 100.0 \\
\hline \multicolumn{3}{|l|}{ Nationality } \\
\hline Other nationalities & 72314 & 70.7 \\
\hline Qatari & 30028 & 29.3 \\
\hline Total & 102342 & 100.0 \\
\hline \multicolumn{3}{|l|}{$\begin{array}{l}\text { Vitamin D therapy before the last serum } \\
\text { vitamin D test }\end{array}$} \\
\hline No & 70818 & 68.9 \\
\hline Yes & 31903 & 31.1 \\
\hline Total & 102721 & 100.0 \\
\hline \multicolumn{3}{|l|}{ BMI measurement } \\
\hline Acceptable $(<25)$ & 18108 & 23.2 \\
\hline Overweight (25-29.9) & 26523 & 34.0 \\
\hline Grade 1 or low risk obesity (30-34.9) & 19549 & 25.1 \\
\hline $\begin{array}{l}\text { Grade } 2 \text { or moderate risk obesity } \\
(35-39.9)\end{array}$ & 9008 & 11.6 \\
\hline Grade 3 obesity (morbid obesity) (40+) & 4779 & 6.1 \\
\hline Total & 77967 & 100.0 \\
\hline
\end{tabular}

BMI, body mass index.

Figure 1 demonstrates the prevalence rate of vitamin D insufficiency, deficiency and severe deficiency among treated and untreated study participants.

As shown in table 2, the relation between sociodemographic factors and vitamin D status is relatively affected by the cut-off values of vitamin $\mathrm{D}$. Table 2 also shows there is no obvious or consistent seasonal variations in prevalence rate of vitamin $\mathrm{D}$ deficiency at any of the three tested cut-off values.

Table 2 shows age had a strong association with vitamin $\mathrm{D}$ deficiency status. In addition, age is known to be associated with BMI and other risk factors studied. Therefore, age qualifies as a strong confounder for any association between explanatory variables tested and the deficiency status. Undertaking a stratified analysis, adjusting for age as a confounder offers a solution to adjust for this undesired confounding effect.

After adjusting for age group, the association between gender, nationality, season, BMI and selected chronic

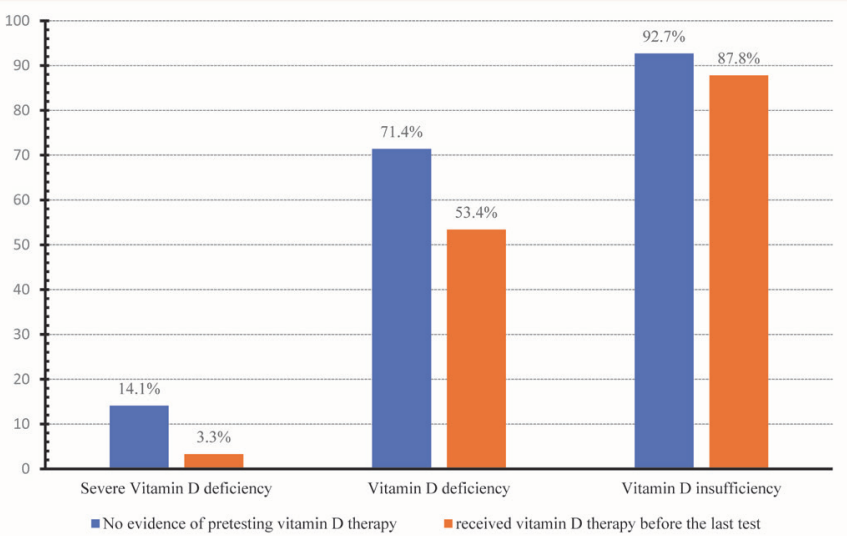

Figure 1 Among study participants with no evidence of prior vitamin $\mathrm{D}$ replacement therapy, the prevalence rate of the severe form of vitamin D deficiency (serum level $<10 \mathrm{ng} /$ $\mathrm{mL}$ ) was $14.1 \%$ and this rate declined to $3.3 \%$ among treated individuals. on the other side, the prevalence rate of vitamin D deficiency (serum level $<20 \mathrm{ng} / \mathrm{mL}$ ) was $71.4 \%$ among non-treated study participants compared with $53.4 \%$ among treated ones. A third cut-off value for defining vitamin $D$ insufficiency is set at $<30 \mathrm{ng} / \mathrm{mL}$, at this level the prevalence rate was as high as $92.7 \%$ among the non-treated group reduced slightly to $87.8 \%$ among the treated group.

health conditions with the prevalence of severe vitamin D deficiency among individuals with no evidence of vitamin $\mathrm{D}$ therapy is shown in table 3 .

Multivariate discriminant analysis was used to predict a severe vitamin D status based on age, nationality, gender, BMI and comorbid chronic conditions. As shown in table 4 , age, gender and nationality were among the top three factors that predicts a severe form of vitamin D deficiency. An older age is associated with a decreased risk of having a severe deficiency status, like the effect of being a male. Whereas Qatari nationality is associated with a higher probability of having severe vitamin $\mathrm{D}$ deficiency. Although a higher BMI would be more predictive of severe deficiency, it was at the bottom of the list of predictor variables. Among the chronic conditions included in the model, hypertension, cardiovascular diseases and stroke increased the risk of having an associated severe vitamin $\mathrm{D}$ deficiency status. While, diabetes and asthma were associated with a lower probability of having the outcome.

In addition, a model (formula) was provided to predict the risk of having an associated severe vitamin D deficiency based on all the variables discussed previously. The formula can calculate the discriminant score ' $\mathrm{D}$ '. If $\mathrm{D}$ is less than -0.245 then the individual is considered at risk of having severe vitamin D deficiency. The more extreme the calculated $\mathrm{D}$ on the negative side the higher is the probability for the individual to have this severe form of vitamin $\mathrm{D}$ deficiency.

\section{DISCUSSION}

This study explored the status of serum vitamin $\mathrm{D}$ among individuals accessing PHCC healthcare centres in Qatar. 
Table 2 The prevalence of selected outcomes based on different serum vitamin D cut-off values for study participants with no evidence of vitamin $\mathrm{D}$ therapy before testing stratified by sociodemographic variables

\begin{tabular}{|c|c|c|c|c|c|c|c|}
\hline & \multirow{2}{*}{$\begin{array}{l}\text { Total } \\
\mathbf{N}\end{array}$} & \multicolumn{2}{|c|}{$\begin{array}{l}\text { Severe vitamin D } \\
\text { deficiency }\end{array}$} & \multicolumn{2}{|c|}{ Vitamin D deficiency } & \multicolumn{2}{|c|}{ Vitamin D insufficiency } \\
\hline & & $\mathbf{N}$ & $\%$ & $\mathbf{N}$ & $\%$ & $\mathbf{N}$ & $\%$ \\
\hline \multicolumn{8}{|l|}{ Age group in years } \\
\hline $18-29$ & 17862 & 4712 & 26.4 & 14610 & 81.8 & 17036 & 95.4 \\
\hline $30-39$ & 22788 & 2951 & 12.9 & 16565 & 72.7 & 21276 & 93.4 \\
\hline $40-49$ & 16808 & 1536 & 9.1 & 11482 & 68.3 & 15522 & 92.3 \\
\hline $50-65$ & 13234 & 775 & 5.9 & 7847 & 59.3 & 11711 & 88.5 \\
\hline \multicolumn{8}{|l|}{ Gender } \\
\hline Female & 44773 & 7459 & 16.7 & 32649 & 72.9 & 41328 & 92.3 \\
\hline Male & 25916 & 2514 & 9.7 & 17852 & 68.9 & 24214 & 93.4 \\
\hline \multicolumn{8}{|l|}{ Nationality } \\
\hline Other nationalities & 51158 & 6277 & 12.3 & 36344 & 71 & 47905 & 93.6 \\
\hline Qatari & 19534 & 3697 & 18.9 & 14160 & 72.5 & 17640 & 90.3 \\
\hline \multicolumn{8}{|l|}{$\begin{array}{l}\text { Season (year quarter) of testing for serum } \\
\text { vitamin D }\end{array}$} \\
\hline First quarter & 14691 & 2085 & 14.2 & 10697 & 72.8 & 13753 & 93.6 \\
\hline Second quarter & 15127 & 1807 & 11.9 & 10682 & 70.6 & 14092 & 93.2 \\
\hline Third quarter & 18447 & 2860 & 15.5 & 13545 & 73.4 & 17183 & 93.1 \\
\hline Fourth quarter & 22427 & 3222 & 14.4 & 15580 & 69.5 & 20517 & 91.5 \\
\hline \multicolumn{8}{|l|}{$\mathrm{BMI}\left(\mathrm{kg} / \mathrm{m}^{2}\right)$ measurement in latest visit } \\
\hline Acceptable $(<25)$ & 13079 & 2191 & 16.8 & 9224 & 70.5 & 11997 & 91.7 \\
\hline Overweight (25-29.9) & 17606 & 2257 & 12.8 & 12307 & 69.9 & 16205 & 92.0 \\
\hline Grade 1 or low risk obesity (30-34.9) & 11987 & 1642 & 13.7 & 8676 & 72.4 & 11134 & 92.9 \\
\hline $\begin{array}{l}\text { Grade } 2 \text { or moderate risk obesity } \\
(35-39.9)\end{array}$ & 5313 & 825 & 15.5 & 4042 & 76.1 & 4967 & 93.5 \\
\hline Grade 3 obesity (morbid obesity) (40+) & 2756 & 488 & 17.7 & 2169 & 78.7 & 2585 & 93.8 \\
\hline
\end{tabular}

BMI, body mass index.

Using strict criteria for defining severe vitamin $\mathrm{D}$ deficiency (serum level $<10 \mathrm{ng} / \mathrm{mL}$ ), the prevalence rate was $14.1 \%$. This rate is increased to $71.4 \%$ for the commonly defined deficiency status (serum level $<20 \mathrm{ng} / \mathrm{mL}$ ). Using laxer criteria for defining vitamin D insufficiency would raise the prevalence rate to as high as $92.7 \%$. Although the current study analysed all the population, selection bias is expected to confound the interpretation of findings as vitamin $\mathrm{D}$ serum testing was only done on a quarter of eligible population. No guideline or protocol was used to identify the eligible population.

The high prevalence of vitamin D deficiency observed in the current study is comparable to that found in various subpopulations of the Middle Eastern as well as to that found in previous studies performed in Qatar. A systematic review of evidence in Qatar reported the weighted-average prevalence of vitamin D insufficiency of $90.4 \%{ }^{12}$ Another systematic review found that severe vitamin D deficiency $(<10 \mathrm{ng} / \mathrm{mL})$ was most common in South Asia and the Middle East. ${ }^{22}$ The prevalence of vitamin $\mathrm{D}$ deficiency in UAE was $85.4 \% .^{16}$ In another study from Saudi Arabia conducted on adult males aged 20-74 years old, $87.8 \%$ had vitamin D level $<20 \mathrm{ng} / \mathrm{mL} .^{11}$ Similar reports of high prevalence of vitamin D deficiency and insufficiency status were also reported for Jordanian and Moroccan women. ${ }^{1317}$

Globally, vitamin D insufficiency is prevalent in all regions of the world. ${ }^{22}$ In the USA, the overall prevalence rate of vitamin D deficiency $(\leq 20 \mathrm{ng} / \mathrm{mL})$ was $41.6 \%$ among adults, with the higher rates in blacks $(82.1 \%)$ and Hispanics $(69.2 \%) .^{23}$ The prevalence of vitamin D insufficiency in Qatar is comparable to that in nearby countries (Gulf and Middle East and North Africa 'MENA' countries), while it was much higher than that in USA. A guideline for treating vitamin $\mathrm{D}$ deficiency is available in PHCC for paediatric age group, however, one for adults is yet to be developed. This might explain the high prevalence of vitamin D insufficiency in PHCC population, which is like the less privileged population sectors of the USA. Other factors may also contribute in explaining differences between populations like skin pigmentation, type of clothing and amount of physical activity. ${ }^{24}$ 
Table 3 The prevalence of severe vitamin $D$ deficiency $(<10 \mathrm{ng} / \mathrm{mL})$ among study participants with no evidence of vitamin D replacement therapy before testing by selected explanatory variables after adjusting for age group

\begin{tabular}{llr} 
& $\begin{array}{l}\text { Severe vitamin } \\
\text { D deficiency } \\
\text { (<10 ng/mL) }\end{array}$ \\
\hline Notal & N $\quad \%$
\end{tabular}

Gender

18-29 years of age

\begin{tabular}{|c|c|c|c|}
\hline Female & 13712 & 3900 & 28.4 \\
\hline Male & 4150 & 812 & 19.6 \\
\hline \multicolumn{4}{|c|}{$30-39$ years of age } \\
\hline Female & 15121 & 2190 & 14.5 \\
\hline Male & 7666 & 761 & 9.9 \\
\hline \multicolumn{4}{|c|}{$40-49$ years of age } \\
\hline Female & 9528 & 999 & 10.5 \\
\hline Male & 7278 & 536 & 7.4 \\
\hline \multicolumn{4}{|c|}{$50-65$ years of age } \\
\hline Female & 6412 & 370 & 5.8 \\
\hline Male & 6822 & 405 & 5.9 \\
\hline
\end{tabular}

\section{Nationality}

18-29 years of age

$\begin{array}{lrrr}\text { Other nationalities } & 10884 & 2563 & 23.5 \\ \text { Qatari } & 6978 & 2149 & 30.8\end{array}$

30-39 years of age

$\begin{array}{lrrr}\text { Other nationalities } & 18082 & 2164 & 12.0 \\ \text { Qatari } & 4706 & 787 & 16.7 \\ \begin{array}{l}\text { 40-49 years of age } \\ \text { Other nationalities }\end{array} & 12815 & 1032 & 8.1 \\ \text { Qatari } & 3993 & 504 & 12.6 \\ \begin{array}{l}\text { 50-65 years of age } \\ \text { Other nationalities }\end{array} & 9377 & 518 & \\ \text { Qatari } & 3857 & 257 & 6.5\end{array}$

Season (year quarter)

18-29 years of age

\begin{tabular}{|lrrr}
\hline First quarter & 3683 & 967 & 26.3 \\
\hline Second quarter & 3730 & 910 & 24.4 \\
\hline Third quarter & 5062 & 1393 & 27.5 \\
\hline Fourth quarter & 5387 & 1442 & 26.8 \\
\hline 30-39 years of age & & & \\
\hline First quarter & 4903 & 643 & 13.1 \\
\hline Second quarter & 5126 & 536 & 10.5 \\
\hline Third quarter & 5810 & 816 & 14.0 \\
\hline Fourth quarter & 6949 & 956 & 13.8 \\
\hline 40-49 years of age & & & \\
\hline First quarter & 3430 & 312 & 9.1 \\
\hline Second quarter & 3551 & 243 & 6.8 \\
\hline Third quarter & 4257 & 442 & 10.4 \\
\hline
\end{tabular}

Continued
Table 3 Continued

\begin{tabular}{|c|c|c|c|}
\hline & \multirow{2}{*}{$\begin{array}{l}\text { Total } \\
\mathbf{N} \\
\end{array}$} & \multicolumn{2}{|c|}{$\begin{array}{l}\text { Severe vitamin } \\
\text { D deficiency } \\
\text { (<10 ng/mL) }\end{array}$} \\
\hline & & $\mathbf{N}$ & $\%$ \\
\hline Fourth quarter & 5570 & 539 & 9.7 \\
\hline \multicolumn{4}{|l|}{$50-65$ years of age } \\
\hline First quarter & 2675 & 163 & 6.1 \\
\hline Second quarter & 2720 & 118 & 4.3 \\
\hline Third quarter & 3318 & 209 & 6.3 \\
\hline Fourth quarter & 4521 & 285 & 6.3 \\
\hline \multicolumn{4}{|l|}{ BMI measurement in latest visit } \\
\hline \multicolumn{4}{|l|}{$18-29$ years of age } \\
\hline Acceptable $(<25)$ & 5850 & 1558 & 26.6 \\
\hline Overweight (25-29.9) & 3912 & 982 & 25.1 \\
\hline $\begin{array}{l}\text { Grade } 1 \text { or low risk obesity } \\
(30-34.9)\end{array}$ & 2193 & 587 & 26.8 \\
\hline $\begin{array}{l}\text { Grade } 2 \text { or moderate risk obesity } \\
(35-39.9)\end{array}$ & 1016 & 316 & 31.1 \\
\hline $\begin{array}{l}\text { Obesity grade } 3 \text { (morbid obesity) } \\
(40+)\end{array}$ & 525 & 178 & 33.9 \\
\hline \multicolumn{4}{|l|}{ 30-39 years of age } \\
\hline Acceptable $(<25)$ & 3826 & 443 & 11.6 \\
\hline Overweight (25-29.9) & 6003 & 776 & 12.9 \\
\hline $\begin{array}{l}\text { Grade } 1 \text { or low risk obesity } \\
(30-34.9)\end{array}$ & 3904 & 557 & 14.3 \\
\hline $\begin{array}{l}\text { Grade } 2 \text { or moderate risk obesity } \\
(35-39.9)\end{array}$ & 1651 & 280 & 17.0 \\
\hline $\begin{array}{l}\text { Obesity grade } 3 \text { (morbid obesity) } \\
(40+)\end{array}$ & 785 & 162 & 20.6 \\
\hline \multicolumn{4}{|l|}{$40-49$ years of age } \\
\hline Acceptable (<25) & 1946 & 137 & 7.0 \\
\hline Overweight (25-29.9) & 4239 & 346 & 8.2 \\
\hline $\begin{array}{l}\text { Grade } 1 \text { or low risk obesity } \\
(30-34.9)\end{array}$ & 3191 & 340 & 10.7 \\
\hline $\begin{array}{l}\text { Grade } 2 \text { or moderate risk obesity } \\
(35-39.9)\end{array}$ & 1339 & 141 & 10.5 \\
\hline $\begin{array}{l}\text { Obesity grade } 3 \text { (morbid obesity) } \\
(40+)\end{array}$ & 742 & 97 & 13.1 \\
\hline \multicolumn{4}{|l|}{ 50-65 years of age } \\
\hline Acceptable $(<25)$ & 1457 & 53 & 3.6 \\
\hline Overweight (25-29.9) & 3452 & 153 & 4.4 \\
\hline $\begin{array}{l}\text { Grade } 1 \text { or low risk obesity } \\
(30-34.9)\end{array}$ & 2699 & 158 & 5.9 \\
\hline $\begin{array}{l}\text { Grade } 2 \text { or moderate risk obesity } \\
(35-39.9)\end{array}$ & 1307 & 88 & 6.7 \\
\hline $\begin{array}{l}\text { Obesity grade } 3 \text { (morbid obesity) } \\
(40+)\end{array}$ & 704 & 51 & 7.2 \\
\hline \multicolumn{4}{|l|}{ Positive risk factor } \\
\hline \multicolumn{4}{|l|}{$18-29$ years of age } \\
\hline $\begin{array}{l}\text { None of the listed chronic } \\
\text { diseases }\end{array}$ & 14738 & 3922 & 26.6 \\
\hline
\end{tabular}

Continued 


\section{Table 3 Continued}

\begin{tabular}{|c|c|c|c|}
\hline & \multirow{2}{*}{$\begin{array}{l}\text { Total } \\
\mathbf{N} \\
\end{array}$} & \multicolumn{2}{|c|}{$\begin{array}{l}\text { Severe vitamin } \\
\text { D deficiency } \\
\text { (<10 ng/mL) }\end{array}$} \\
\hline & & $\mathbf{N}$ & $\%$ \\
\hline Diabetes & 1716 & 431 & 25.1 \\
\hline Hypertension & 575 & 133 & 23.1 \\
\hline Asthma & 1109 & 301 & 27.1 \\
\hline Stroke & 7 & 2 & 28.6 \\
\hline Cardiovascular disease & 47 & 7 & 14.9 \\
\hline $\begin{array}{l}\text { Any of the listed chronic } \\
\text { diseases }\end{array}$ & 3124 & 790 & 25.3 \\
\hline \multicolumn{4}{|l|}{ 30-39 years of age } \\
\hline $\begin{array}{l}\text { None of the listed chronic } \\
\text { diseases }\end{array}$ & 16333 & 2161 & 13.2 \\
\hline Diabetes & 4093 & 535 & 13.1 \\
\hline Hypertension & 2135 & 217 & 10.2 \\
\hline Asthma & 1286 & 171 & 13.3 \\
\hline Stroke & 18 & 2 & 11.1 \\
\hline Cardiovascular disease & 101 & 12 & 11.9 \\
\hline $\begin{array}{l}\text { Any of the listed chronic } \\
\text { diseases }\end{array}$ & 6455 & 790 & 12.2 \\
\hline \multicolumn{4}{|l|}{$40-49$ years of age } \\
\hline $\begin{array}{l}\text { None of the listed chronic } \\
\text { diseases }\end{array}$ & 9166 & 905 & 9.9 \\
\hline Diabetes & 4608 & 390 & 8.5 \\
\hline Hypertension & 4243 & 320 & 7.5 \\
\hline Asthma & 1241 & 108 & 8.7 \\
\hline Stroke & 43 & 5 & 11.6 \\
\hline Cardiovascular disease & 238 & 14 & 5.9 \\
\hline $\begin{array}{l}\text { Any of the listed chronic } \\
\text { diseases }\end{array}$ & 7642 & 631 & 8.3 \\
\hline \multicolumn{4}{|l|}{ 50-65 years of age } \\
\hline $\begin{array}{l}\text { None of the listed chronic } \\
\text { diseases }\end{array}$ & 3814 & 272 & 7.1 \\
\hline Diabetes & 6603 & 344 & 5.2 \\
\hline Hypertension & 6903 & 349 & 5.1 \\
\hline Asthma & 1441 & 61 & 4.2 \\
\hline Stroke & 88 & 7 & 8.0 \\
\hline Cardiovascular disease & 713 & 38 & 5.3 \\
\hline $\begin{array}{l}\text { Any of the listed chronic } \\
\text { diseases }\end{array}$ & 9420 & 503 & 5.3 \\
\hline
\end{tabular}

BMI, body mass index.

The current study showed a negative relation between the age of participants and the prevalence rate of vitamin D deficiency. The risk of deficiency status is declining with advancing age. Evidence supporting this finding was published in a study among UAE adults showing a positive trend for serum vitamin D level with advancing age. ${ }^{16}$ Other studies supported the association between lower serum vitamin D concentration and younger age. ${ }^{17} 2526$
Table 4 Discriminant analysis with selected explanatory variables to predict study participants with severe vitamin D deficiency differentiating them from those with serum levels of $10+$

\begin{tabular}{lll}
\hline & $\begin{array}{l}\text { Variables ordered by } \\
\text { absolute size of correlation } \\
\text { (pooled within-groups } \\
\text { correlations between } \\
\text { discriminating variables } \\
\text { and standardised canonical } \\
\text { discriminant functions) } \\
\text { within function }\end{array}$ & $\begin{array}{l}\text { Risk of } \\
\text { having } \\
\text { severe } \\
\text { Vitamin D } \\
\text { deficiency }\end{array}$ \\
\hline Age in year & 1 & Decrease \\
\hline Hypertension & 2 & Increase \\
\hline $\begin{array}{l}\text { Male versus Female } \\
\text { Gender }\end{array}$ & 3 & Decrease \\
\hline $\begin{array}{l}\text { Qatari Nationality } \\
\text { versus Others }\end{array}$ & 4 & Increase \\
\hline Diabetes & 5 & Decrease \\
\hline Cardiovascular disease & 6 & Increase \\
\hline Asthma & 7 & Decrease \\
\hline Stroke & 8 & Increase \\
\hline BMI measurement & 9 & Increase \\
\hline
\end{tabular}

BMI, body mass index.

\begin{tabular}{lc}
\hline & $\begin{array}{l}\text { Unstandardised } \\
\text { coefficients }\end{array}$ \\
\hline $\begin{array}{l}\text { Gender (male coded as one and females as } \\
\text { zero) }\end{array}$ & 0.310 \\
\hline Age in year & 0.081 \\
\hline BMI measurement in latest visit & -0.026 \\
\hline $\begin{array}{l}\text { Nationality (Qatari coded as one and others } \\
\text { as zero) }\end{array}$ & -0.531 \\
$\begin{array}{l}\text { Diabetes (coded as one when present and } \\
\text { zero if absent) }\end{array}$ & 0.022 \\
$\begin{array}{l}\text { Hypertension (coded as one when present } \\
\text { and zero if absent) }\end{array}$ & -0.006 \\
$\begin{array}{l}\text { Asthma (coded as one when present and } \\
\text { zero if absent) }\end{array}$ & 0.154 \\
$\begin{array}{l}\text { Stroke (coded as one when present and zero } \\
\text { if absent) }\end{array}$ & -0.345 \\
$\begin{array}{l}\text { Cardiovascular disease (coded as one when } \\
\text { present and zero if absent) }\end{array}$ & -0.188 \\
\hline \begin{tabular}{l} 
(Constant) \\
\hline
\end{tabular} & -2.296 \\
\hline
\end{tabular}

$\mathrm{D}=-2.296+[0.31 \times($ Gender $)]+[0.081 \times($ Age in year) $]+[-0.026 x(B M I$ Measurement in latest visit) $]+[-0.531 x$ (Nationality)]+[0.022x(Diabetes)]+[-0.006x(Hypertension)] $[0.154 \times($ Asthma $)]+[-0.345 \times($ Stroke $)]+[-0.188 \times($ Cardiovascular disease)].

Discriminant score $(D)=-0.245$. If $D<-0.245$ then the individual is expected to have severe vitamin $D$ deficiency.

The explanation for this observation is the use of vitamin D supplementation for elderly people, especially women, who are getting used to taking multivitamin tablets. In addition, clothing habit/lifestyle modification among younger people could provide further explanations. 
Younger people prefer living in apartments and have less outdoor physical activity whereas older people prefer living in houses and have more outdoor physical activity when they were younger and also now. ${ }^{25}$ Still many studies reported evidence for an opposite age association with vitamin D status. These studies reached to a conclusion that older age acts as a predictor for lower vitamin D level. ${ }^{11} 13222728$ Possible explanation for this include shortage in effective programme of prevention and treatment may results in vitamin $\mathrm{D}$ deficiency to be common among elderly. ${ }^{29}$ A decreases in synthesis of vitamin D3 in the skin under influence of UV light with ageing due to insufficient sunlight exposure, and a decreased functional capacity of the skin. ${ }^{30}$ Ageing is usually associated with a decrease in food intake, which may cause concurrent vitamin $\mathrm{D}$ deficiency. ${ }^{31}$

In the current study, the severe form of vitamin D deficiency was more prevalent among females (almost double that of males). This gap would almost disappear when we compare both genders according to the insufficiency status. This finding agrees with a study from UAE reporting an almost similar mean serum vitamin D level for both genders. ${ }^{16}$ In a Jordanian study conducted on study participants aged $>18$ years, the prevalence of low vitamin D status $(<30 \mathrm{ng} / \mathrm{mL})$ was $37.3 \%$ in females compared with only $5.1 \%$ in males. Dress style for females in Arabic culture was independently related to low vitamin D status; women wearing 'Hijab' (adjusted $\mathrm{OR}=1.7, \mathrm{p}=0.004$ ) or 'Niqab' (adjusted $\mathrm{OR}=1.5$, $\mathrm{p}=0.061$ ) were at a higher risk for low vitamin D status than were western-dressed women. ${ }^{27}$ Other studies highlighted the higher risk of females for a deficiency status. ${ }^{22} 2532$

In the current study, Qatari nationality (local population) had the highest rate of severe deficiency $(18.9 \%)$ compared with other nationalities $(12.3 \%)$. The UAE study showed a statistically significant lower mean vitamin D level $(19.1 \mathrm{ng} / \mathrm{mL})$ among the local population compared with expatriates $(20.07 \mathrm{ng} / \mathrm{mL}) .{ }^{16}$ The type of dress covering the whole body (in females as well as males) may explain such a difference.

Our study reports highest prevalence of severe vitamin $\mathrm{D}$ deficiency among obese individuals. In addition, a positive trend for severe vitamin D deficiency was observed with increasing BMI. Many studies supported the fact that low serum vitamin $\mathrm{D}$ levels are significantly more common among obese people with BMI $>30 .{ }^{11233233}$ Obesity-associated low vitamin D levels is possible due to the decreased bioavailability of vitamin D from cutaneous and dietary sources among obese people. ${ }^{5}$

Current study demonstrated that severe deficiency was less common among adults sampled during spring (second quarter), compared with other seasons. It seems that having good weather during this time of the year in Qatar may allow sun exposure which stimulate production of vitamin D in the body. Saudi Arabia showed that hypovitaminosis D was more common during spring and summer. ${ }^{11}$ Another study from Morocco showed that vitamin D insufficiency was very common in healthy adult Moroccan women during summer. ${ }^{13}$ In Europe, surprisingly vitamin D concentrations were higher in the Northern European and Scandinavian countries compared with Southern Europe. This could be partly explained by avoidance of sunlight exposure and inability to perform daily activities in Southern Europe compared with the Northern. ${ }^{31}$

None of the five chronic conditions explored in the current study (diabetes, hypertension, asthma, stroke and cardiovascular disease) had an obvious association with severe vitamin D deficiency status in bivariate analysis. The multivariate modelling, however showed that (adjusting for age, gender, BMI and nationality and each of the included chronic conditions) hypertension, cardiovascular diseases and stroke increased the risk of having an associated severe vitamin D deficiency status. Whereas, diabetes and asthma were associated with a lower probability of having an associated deficiency status. There is an abundance of literature discussing the association between these chronic conditions and vitamin D status. Some suggested that vitamin D plays an important role in a broad range of organ functions, including cardiovascular health and thus a deficiency status would be associated with a significant increase in the prevalence of vascular disease, coronary artery disease, myocardial infarction, heart failure and stroke. ${ }^{34}$ This plausible explanation for a beneficial role of vitamin $\mathrm{D}$ in preventing or ameliorating the above listed conditions was consistently challenged by another group of literature failing to document a link between these conditions and vitamin D.

Evidence in favour of a possible link between cardiovascular problems and low vitamin $\mathrm{D}$ status has been reported in studies. The prevalence of vitamin D insufficiency $(<30 \mathrm{ng} / \mathrm{mL})$ was higher in participants with selected cardiovascular disease risk factors, including obesity, hypertension, diabetes mellitus, hypertriglyceridaemia and hypercholesterolaemia. ${ }^{32}{ }^{35}$ The results of a study from India found a significant correlation between the prevalence of vitamin D deficiency and acute coronary syndrome in comparison to healthy controls. In accordance to that study, vitamin D deficiency was associated with a statistically significant increase in the prevalence of peripheral vascular disease. ${ }^{36}$ A study conducted on 239 patients with coronary artery disease revealed very high prevalence (up to $96 \%$ ) of abnormally low vitamin D levels. ${ }^{37}$ Severe vitamin D deficiency $(<10 \mathrm{ng} / \mathrm{mL})$ was shown to be independently associated with in-hospital cardiovascular mortality in 206 patients with acute coronary syndromes. ${ }^{38}$ Severe vitamin D deficiency has been suggested to be strongly associated with sudden cardiac death, cardiovascular events and mortality and borderline associated with stroke and fatal infection. ${ }^{39}$ In a cohort study conducted in USA, vitamin D deficiency was associated with an increased risk of all stroke cases (haemorrhagic and ischaemic).$^{40}$ Other studies failed to document a link between cardiovascular disease and vitamin D. In the study by Park and Lee, serum vitamin D levels did not differ significantly between the cardiovascular disease and non-cardiovascular disease groups. ${ }^{41}$ Similarly, the 
analysis carried in high-risk patients with stable coronary heart disease does not support a prognostic value of baseline-vitamin D levels for secondary cardiovascular event incidence or all-cause mortality. ${ }^{42}$

Several studies assessed the association between serum levels of vitamin $\mathrm{D}$ and select cardiovascular disease risk factors in adults. Vitamin D level was significantly lower in hypertensives cases. ${ }^{23} 3235$ In addition, vitamin D deficiency was associated with a significant increases in the prevalence of hypertension. ${ }^{3436}$ Accumulating evidence derived from a systematic review favours the hypothesis that vitamin D deficiency contributes to arterial hypertension. ${ }^{43}$ Two cohort studies monitored vitamin D levels for $4-8$ years, these studies showed that the relative risk (adjusted by multivariate modelling) for incident hypertension for individuals with vitamin $\mathrm{D}$ deficiency $(<15 \mathrm{ng} / \mathrm{mL})$ was increased by six times in males and two times in females compared with those with a plasma level $\geq 30 \mathrm{ng} / \mathrm{mL}$. ${ }^{44}$ Increasing vitamin $\mathrm{D}$ level in the blood has been directly or indirectly shown to reduce blood pressure in several studies. ${ }^{456}$ Other studies failed to document a beneficial effect for vitamin D supplementation. A large prospective study by Forman et al in 2005 found no association between vitamin D intake from diet or as supplements and the risk of incident hypertension. ${ }^{47}$ In addition, several clinical trials using supplementation of vitamin $\mathrm{D}$ did not show any significant decrease in blood pressure. $^{48-50}$

Conflicting research evidence exits about the possible relation between vitamin $\mathrm{D}$ and diabetes mellitus. Some literature supported a positive association and suggested that hypovitaminosis D may be a significant risk factor for glucose intolerance in some, but not all, populations. Individuals with vitamin $D$ deficiency status $(<20 \mathrm{ng} / \mathrm{mL})$ had a greater prevalence of components of metabolic syndromes including type 2 diabetes than did those with acceptable vitamin D status. ${ }^{51}$ Type 2 diabetes patients had a higher incidence of hypovitaminosis D in different studies. ${ }^{23252} \mathrm{In}$ addition, vitamin $\mathrm{D}$ deficiency was associated with a significant increase in prevalence and likelihood of developing of diabetes. ${ }^{34-36}$ Two studies indicated that prolonged treatment of osteomalacia with vitamin $\mathrm{D}$ increases insulin secretion and improves glucose tolerance. ${ }^{534}$ Other literature failed to show a positive association or even showed an inverse association. Data from the Third National Health and Nutrition Examination Survey showed an inverse association between vitamin $\mathrm{D}$ status and diabetes in nonHispanic white and Mexican American people, but not in non-Hispanic black people. An explanation for the lack of association could be the existence of a variable threshold effect among different ethnic groups. ${ }^{28}$ In another study conducted on 1071 randomly selected white English individuals aged $40-65$ years, serum vitamin D levels were not related to glucose status. ${ }^{55}$

Many studies were published about a possible role for vitamin D in childhood asthma. In adults, such an association was also subject to conflicting evidence. Among supporters for a possible positive association between asthma and low vitamin $\mathrm{D}$ is a study among
African American showing that vitamin D deficiency was significantly greater among cases than controls $(86 \%$ vs $19 \%) .{ }^{56}$ Conversely, another study showed that vitamin D deficiency was more frequent among healthy control compared with asthmatic cases. ${ }^{57}$ In addition, two studies demonstrated that vitamin $\mathrm{D}$ supplementation increases the risk of allergic asthma. ${ }^{58} 59$

The current study is subject to well-known sources of bias, which needs to be addressed as limitations. The study used an analytical cross-sectional design, therefore any reported associations between selected explanatory variables and vitamin $\mathrm{D}$ status or absence of such explored associations should not be interpreted in the sense of risk or predictors. Since temporality as a criterion of causality cannot be verified in a cross-sectional design. One is unable to decide whether vitamin D deficiency status resulted in a specific disease status or that status was the precipitating factor for the deficiency status. Only age, gender and to some extent nationality are expected to be incriminated as risk factors, since these are fixed criteria. In addition, difference in the applied diagnostic criteria and laboratory cut-off values in identifying vitamin $\mathrm{D}$ deficiency and insufficiency across different studies may limit the ability of a fair comparison between studies. Selection bias is always a limitation in observational designs. Although the whole population satisfying the inclusion criteria was analysed in the current study, they still represent a selected group of approximately one fourth of the total population seeking primary healthcare services during the 1-year study period. This part of the population who had their vitamin $\mathrm{D}$ serum tested was not a randomly selected subgroup, since the physicians requesting this biochemical test would have used some special criteria and indications to order the test, which is not standardised to follow a clinical guideline. Therefore, not all people had equal chances to be included in this study and the results cannot be generalised to every adult seeking health services in primary care setting. Based on the preceding argument the researcher is inclined to expect the reported results for vitamin $\mathrm{D}$ deficiency to represent a slight overestimate of the real situation.

\section{CONCLUSION}

Although not comprehensive and nationally representative, this study is suggestive of a higher prevalence of vitamin D deficiency among young adults, females, Qatari nationality and those with higher BMI. No clear association was observed using bivariate analysis for any of the five chronic conditions explored in the current study with severe deficiency status. Multivariate modelling showed that hypertension, cardiovascular diseases and stroke increased the risk of having an associated severe vitamin D deficiency status.

\section{Recommendations}

The high prevalence of vitamin $\mathrm{D}$ deficiency was based on a cut-off value of $<20 \mathrm{ng} / \mathrm{mL}$ among adult population of PHC service users. Further evidence is required to 
justify the use of such a cut-off value or defining a new cut-off value that is more suitable for Qatar. In addition, an intervention study is needed to study the effectiveness of different treatment protocols in PHCG population.

Acknowledgements We are extremely grateful to everyone who contributed to this work, especially the HIM department in PHCC.

Contributors AJALZ and HQ designed the study and wrote the primary proposal. AJALZ managed data collection. MS, HQ and AJALZ did the literature review. AAN and AJALZ did data analysis, results interpretation and wrote the discussion. AJALZ drafted the manuscript. HQ, AAN and MS revised the manuscript. AJALZ finalised and submitted the manuscript. AAN and MS replied to reviewers comments and amended the manuscript accordingly.

Funding The authors have not declared a specific grant for this research from any funding agency in the public, commercial or not-for-profit sectors.

Competing interests None declared.

Patient consent for publication Not required.

Ethics approval This study was conducted with integrity according to generally accepted ethical principles and was approved by the PHCC's Research Committee.

Provenance and peer review Not commissioned; externally peer reviewed.

Data availability statement № data are available.

Open access This is an open access article distributed in accordance with the Creative Commons Attribution Non Commercial (CC BY-NC 4.0) license, which permits others to distribute, remix, adapt, build upon this work non-commercially, and license their derivative works on different terms, provided the original work is properly cited, appropriate credit is given, any changes made indicated, and the use is non-commercial. See: http://creativecommons.org/licenses/by-nc/4.0/.

\section{REFERENCES}

1. Hollis BW. Circulating 25-hydroxyvitamin D levels indicative of vitamin D sufficiency: implications for establishing a new effective dietary intake recommendation for vitamin D. J Nutr 2005;135:317-22.

2. Freedman DM, Looker AC, Chang S-C, et al. Prospective study of serum vitamin D and cancer mortality in the United States. J NatI Cancer Inst 2007;99:1594-602.

3. Canadian nutrient file. Ottawa (on): health Canada, 1997. Available: www.hcsc.c.ca/fn-an/nutrition/fiche-nutri-data/index_e.html [Accessed 1 Dec 2018].

4. Bassil D, Rahme M, Hoteit M, et al. Hypovitaminosis D in the middle East and North Africa. Dermatoendocrinol 2013;5:274-98.

5. Wortsman J, Matsuoka LY, Chen TC, et al. Decreased bioavailability of vitamin D in obesity. Am J Clin Nutr 2000;72:690-3.

6. D BL T. Vitamin D insufficiency. Mayo Clin Proc 2011;86:50-60.

7. LeBlanc ES, Zakher B, Daeges M, et al. Screening for vitamin D deficiency: a systematic review for the U.S. preventive services Task force. Ann Intern Med 2015;162:109.

8. Hanley DA, Cranney A, Jones G, et al. Guidelines Committee of the scientific Advisory Council of osteoporosis Canada. vitamin $D$ in adult health and disease: a review and guideline statement from osteoporosis Canada (summary). Can Med Assoc J 2010;182:1315-9.

9. William Reed Business Media Ltd. Midday sun is good for vitamin D levels, say scientists. Available: https://www.nutraingredients.com/ Article/2005/05/27/Midday-sun-is-good-for-vitamin-D-levels-sayscientists [Accessed 28 Nov 2018].

10. Holick MF. Sunlight and vitamin D for bone health and prevention of autoimmune diseases, cancers, and cardiovascular disease. Am J Clin Nutr 2004;80:1678S-88.

11. Ardawi M-SM, Sibiany AM, Bakhsh TM, et al. High prevalence of vitamin D deficiency among healthy Saudi Arabian men: relationship to bone mineral density, parathyroid hormone, bone turnover markers, and lifestyle factors. Osteoporos Int 2012;23:675-86.

12. Badawi A, Arora P, Sadoun E, et al. Prevalence of vitamin D insufficiency in Qatar: a systematic review. J Public health Res 2012:1:36.

13. Allali F, El Aichaoui S, Khazani $\mathrm{H}$, et al. High prevalence of hypovitaminosis D in Morocco: relationship to lifestyle, physical performance, bone markers, and bone mineral density. Semin Arthritis Rheum 2009;38:444-51.
14. Joergensen $C$, Hovind P, Schmedes A, et al. Vitamin D levels, microvascular complications, and mortality in type 1 diabetes. Diabetes Care 2011;34:1081-5.

15. Mahdy SM, Al-Emadi SA, Khanjar IA, et al. Vitamin D status in health care professionals in Qatar. Saudi Med J 2010;31:74-7.

16. Yammine $\mathrm{K}, \mathrm{Al}$ Adham $\mathrm{H}$. The status of serum vitamin $\mathrm{D}$ in the population of the United Arab Emirates. East Mediterr Health $J$ 2016;22:682-6.

17. Nichols EK, Khatib IMD, Aburto NJ, et al. Vitamin D status and determinants of deficiency among non-pregnant Jordanian women of reproductive age. Eur J Clin Nutr 2012;66:751-6.

18. Cutillas-Marco E, Prosper AF, Grant WB, et al. Vitamin D status and hypercholesterolemia in Spanish general population. Dermatoendocrinol 2013;5:358-62.

19. Wolf M, Shah A, Gutierrez O, et al. Vitamin D levels and early mortality among incident hemodialysis patients. Kidney Int 2007;72:1004-13.

20. Pittas AG, Dawson-Hughes B, Li T, et al. Vitamin D and calcium intake in relation to type 2 diabetes in women. Diabetes Care 2006;29:650-6.

21. Brijesh M, Saurav P. Prevalence of vitamin D deficiency in type-2 diabetes mellitus patients and its correlation with glycemic control. Int J Bioassays 2014;3:3313-7.

22. Mithal A, Wahl DA, Bonjour J-P, et al. Global vitamin D status and determinants of hypovitaminosis D. Osteoporosis International 2009;20:1807-20.

23. Forrest KYZ, Stuhldreher WL. Prevalence and correlates of vitamin D deficiency in US adults. Nutr Res 2011;31:48-54.

24. Matsuoka LY, Wortsman J, Hollis BW. Use of topical sunscreen for the evaluation of regional synthesis of vitamin D3. J Am Acad Dermatol 1990;22:772-5.

25. Hovsepian S, Amini M, Aminorroaya A, et al. Prevalence of vitamin D deficiency among adult population of Isfahan City, Iran. J Heal Popul Nutr 2011;29.

26. Kaykhaei MA, Hashemi M, Narouie B, et al. High prevalence of vitamin D deficiency in Zahedan, Southeast Iran. Ann Nutr Metab 2011;58:37-41.

27. Batieha A, Khader $Y$, Jaddou $H$, et al. Vitamin D status in Jordan: dress style and gender discrepancies. Ann Nutr Metab 2011;58:10-18.

28. Scragg R, Sowers M, Bell C. Third National health and nutrition examination survey. serum 25-hydroxyvitamin D, diabetes, and ethnicity in the third National health and nutrition examination survey. Diabetes Care 2004;27:2813-8.

29. Goldray D, Mizrahi-Sasson E, Merdler C, et al. Vitamin D deficiency in elderly patients in a general Hospital. J Am Geriatr Soc 1989;37:589-92.

30. Lips P. Vitamin D deficiency and secondary hyperparathyroidism in the elderly: consequences for bone loss and fractures and therapeutic implications. Endocr Rev 2001;22:477-501.

31. van der Wielen RPJ, de Groot LCPGM, van Staveren WA, et al. Serum vitamin D concentrations among elderly people in Europe. The Lancet 1995;346:207-10.

32. Martins D, Wolf M, Pan D, et al. Prevalence of cardiovascular risk factors and the serum levels of 25-hydroxyvitamin D in the United States: data from the third National health and nutrition examination survey. Arch Intern Med 2007;167:1159-65.

33. Baradaran A, Behradmanesh S, Nasri H. Association of body mass index and serum vitamin D level in healthy Iranian adolescents. Endokrynol Pol 2012;63:29-33.

34. Anderson JL, May HT, Horne BD, et al. Relation of vitamin D deficiency to cardiovascular risk factors, disease status, and incident events in a general healthcare population. Am J Cardiol 2010;106:963-8.

35. Vacek JL, Vanga SR, Good M, et al. Vitamin D deficiency and supplementation and relation to cardiovascular health. Am J Cardiol 2012;109:359-63.

36. Bhougalv BN, Kundal V, Behl K, et al. Prevalence of vitamin D deficiency in critically ill patients of cerebrovascular accidents. JK Sci 2017;18:211-5.

37. Lee JH, Gadi R, Spertus JA, et al. Prevalence of vitamin D deficiency in patients with acute myocardial infarction. Am J Cardiol 2011;107:1636-8.

38. Correia LCL, Sodré F, Garcia G, et al. Relation of severe deficiency of vitamin $\mathrm{D}$ to cardiovascular mortality during acute coronary syndromes. Am J Cardiol 2013;111:324-7.

39. Drechsler C, Pilz S, Obermayer-Pietsch B, et al. Vitamin D deficiency is associated with sudden cardiac death, combined cardiovascular events, and mortality in haemodialysis patients. Eur Heart $J$ 2010;31:2253-61. 
40. Judd SE, Morgan CJ, Panwar B, et al. Vitamin D deficiency is associated with stroke in black and white participants of the REGARDS study. Stroke 2014;11:93-102.

41. Park S, Lee B-K. Vitamin D deficiency is an independent risk factor for cardiovascular disease in Koreans aged $\geq 50$ years: results from the Korean National health and nutrition examination survey. Nutr Res Pract 2012:6:162-8.

42. Grandi NC, Breitling LP, Vossen CY, et al. Serum vitamin D and risk of secondary cardiovascular disease events in patients with stable coronary heart disease. Am Heart J 2010;159:1044-51.

43. Pilz S, Tomaschitz A, Ritz E, et al. Vitamin D status and arterial hypertension: a systematic review. Nat Rev Cardiol 2009;6:621-30.

44. Forman JP, Giovannucci E, Holmes MD, et al. Plasma 25-hydroxyvitamin $D$ levels and risk of incident hypertension. Hypertension 2007;49:1063-9.

45. Krause R, Bühring M, Hopfenmüller W, et al. Ultraviolet B and blood pressure. Lancet 1998;352:709-10.

46. Pfeifer M, Begerow B, Minne HW, et al. Effects of a short-term vitamin $D(3)$ and calcium supplementation on blood pressure and parathyroid hormone levels in elderly women. J Clin Endocrinol Metab 2001;86:1633-7.

47. Forman JP, Bischoff-Ferrari HA, Willett WC, et al. Vitamin D intake and risk of incident hypertension: results from three large prospective cohort studies. Hypertens 2005;46:676-82.

48. Margolis KL, Ray RM, Van Horn L, et al. Effect of calcium and vitamin D supplementation on blood pressure: The women's health initiative randomized trial. Hypertension 2008;52:847-55.

49. Orwoll ES, Oviatt S. Relationship of mineral metabolism and longterm calcium and cholecalciferol supplementation to blood pressure in normotensive men. Am J Clin Nutr 1990;52:717-21.
50. Scragg R, Khaw KT, Murphy S. Effect of winter oral vitamin D3 supplementation on cardiovascular risk factors in elderly adults. Eur $J$ Clin Nutr 1995;49:640-6.

51. Chiu KC, Chu A, Go VLW, et al. Hypovitaminosis D is associated with insulin resistance and beta cell dysfunction. Am J Clin Nutr 2004;79:820-5.

52. Takiishi T, Gysemans $C$, Bouillon $R$, et al. Vitamin $D$ and diabetes. Rheum Dis Clin North Am 2012;38:179-206.

53. Boucher BJ. Inadequate vitamin D status: does it contribute to the disorders comprising syndrome ' $X$ '? Br J Nutr 1998;79:315-27.

54. Zittermann A. Vitamin D in preventive medicine: are we ignoring the evidence? Br J Nutr 2003;89:552-72.

55. Wareham NJ, Byrne CD, Carr C, et al. Glucose intolerance is associated with altered calcium homeostasis: a possible link between increased serum calcium concentration and cardiovascular disease mortality. Metabolism 1997;46:1171-7.

56. Freishtat RJ, Iqbal SF, Pillai DK, et al. High prevalence of vitamin $D$ deficiency among inner-city African American youth with asthma in Washington, DC. J Pediatr 2010;156:948-52.

57. Goleva E, Searing DA, Jackson LP, et al. Steroid requirements and immune associations with vitamin $D$ are stronger in children than adults with asthma. J Allergy Clin Immunol 2012;129:1243-51.

58. Wist M. The vitamin D slant on allergy. Pediatr Allergy Immunol 2006;17:477-83

59. Hyppönen $E$, Sovio $U$, Wjst M, et al. Infant vitamin D supplementation and allergic conditions in adulthood: Northern Finland birth cohort 1966. Ann N Y Acad Sci 2004;1037:84-95. 